GRASAS Y ACEITES 69 (1)

January-March 2018, e234

ISSN-L: 0017-3495

https://doi.org/10.3989/gya.0777171

\title{
Potential of Annona muricata L. seed oil: phytochemical and nutritional characterization associated with non-toxicity
}

\author{
L.C. Pinto ${ }^{a}$, C.O. de Souza ${ }^{\mathrm{b}}$, S.A. de Souza ${ }^{\mathrm{c}}$, H.B. da Silva ${ }^{\mathrm{d}}$, R.R. da Silva ${ }^{\mathrm{h}}$, A.T. Cerqueira-Lima ${ }^{\mathrm{d}}$,
} T.O. Teixeira ${ }^{d}$, T.M.S. da Silva ${ }^{c}$, K.C.P. Medeiros ${ }^{\mathrm{e}}$, M. Bittencourt ${ }^{\mathrm{f}}$, H.R. Brandão ${ }^{\mathrm{f}}$, J.I. Druzian ${ }^{\mathrm{b}}$, A.S. Conceição ${ }^{g}$, M.V. Lopes ${ }^{\mathrm{h}}$ and C.A. Figueiredo ${ }^{\mathrm{d}, 凶}$

${ }^{a}$ Department of Food Science, School of Nutrition, Federal University of Bahia.

${ }^{b}$ Faculty of Pharmacy, Federal University of Bahia, Brazil.

${ }^{\mathrm{c}}$ Laboratory of Phytochemistry Bioprospecting, Federal Rural University of Pernambuco, Brazil.

${ }^{\mathrm{d}}$ Institute of Health Sciences, Federal University of Bahia.Av. Reitor Miguel Calmon, s/n, Canela, CEP: 41100-110 - Salvador, Bahia, Brasil.

${ }^{\text {e}}$ Federal University of Rio Grande do Norte, Brazil.

${ }_{\mathrm{f}}^{\mathrm{f}}$ Veterinary Hospital UNIME (HOSVET). Metropolitan Union of Education and Culture (UNIME), Lauro de Freitas, Bahia, Brazil.

${ }^{g}$ University of Bahia State, Department of Education, Herbarium of the State University of Bahia (HUNEB) Paulo Afonso, Brazil.

${ }^{\mathrm{h}}$ Department of Life Sciences, State University of Bahia, Brazil.

${ }^{\square}$ Corresponding author: cavfigueiredo@gmail.com

Submitted: 11 July 2017; Accepted: 16 October 2017

SUMMARY: The aim of this study was to evaluate the nutritional quality, phenolic compounds, fatty acid and antioxidant activity in vitro as well as a toxicological screening of $A$. muricata seed oil in vivo. The chemical composition and quantification of phenolic compounds were determined by the Adolfo Lutz Institute normative. The antioxidant activity was evaluated by DPPH, FRAP and ABTS methods. The oil was extracted by chloroform/ methanol and precipitated crude $(A m P t O)$ and supernatant oils $(A m S O)$ were obtained. The fatty acid profile was evaluated by gas chromatography and total compounds by HPLC-DAD. BALB/C mice received AmPtO and AmSO $\left(0.5\right.$ and $\left.1.0 \mathrm{~mL} \cdot \mathrm{Kg}^{-1}\right)$ for 14 days. Toxicity parameters were assessed. The major fatty acids in the oil were oleic $(39.2 \%)$ and linoleic (33\%). HPLC-DAD suggested the presence of acetogenins (annonacin: 595 [M-H]), with a greater presence in $\mathrm{AmPtO}$. The $\mathrm{AmPtO}$ group showed toxicity, which may be related to the acetogenin content in AmPtO. The AmSO group showed no toxicity and this oil has potential for food or medicinal use.

KEYWORDS: Acetogenins; Annona muricata seeds; Annonacin; Linoleic acid; Oleic acid

RESUMEN: Potencial del aceite de Annona muricata L.: Caracterización nutricional y fitoquímica asociada con no toxicidad. El objetivo de este estudio fue evaluar la calidad nutricional, compuestos fenólicos, ácidos grasos, actividad antioxidante in vitro y evaluación toxicológica del aceite de las semillas de la Annona muricata. La composición química y los compuestos fenólicos se determinaron de acuerdo con las normas del Instituto Adolfo Lutz y la actividad antioxidante por métodos de DPPH, FRAP y ABTS. El aceite fue extraído con cloroformo/metanol obteniéndose un precipitado crudo $(A m P t O)$ y un aceite sobrenadante $(A m S O)$. El perfil de ácidos grasos fue evaluado por cromatografía gaseosa y los compuestos fitoquímicos mediante HPLCDAD. BALB/C recibieron $A m P t O$ y $A m S O\left(0,5\right.$ y $\left.1,0 \mathrm{~mL} \cdot \mathrm{kg}^{-1}\right)$ durante 14 días. Se evaluaron los parámetros bioquímicos e histopatológicos. Los ácidos grasos principales fueron oleico $(39,2 \%)$ y linoleico (33\%). HPLCDAD indicó la presencia de acetogeninas, particularmente anonacina $(595[\mathrm{M}-\mathrm{H}])$, principalmente en $A M P t O$. $A m P t O$ presentó toxicidad y esto puede estar relacionado con las acetogeninas. AmSO no presentó toxicidad y tiene potencial para la alimentación o uso medicinal.

PALABRAS CLAVE: Acetogeninas; Ácido linoleico; Ácido oleico; Anonacina; Semillas de Annona muricata

ORCID: Pinto LC https://orcid.org/0000-0001-7470-7074, Souza CO https://orcid.org/0000-0002-8028-5418, Souza SA https://orcid.org/0000-0001-9689-7614, Silva HB https://orcid.org/0000-0003-1585-9099, Silva RR https://orcid. org/0000-0002-3422-0453, Cerqueira-Lima AT https://orcid.org/0000-0001-7991-4005, Teixeira TO https://orcid. org/0000-0001-7998-2569, Silva TMS https://orcid.org/0000-0003-1887-2598, Medeiros KCP https://orcid.org/00000002-7784-0740, Bittencourt M https://orcid.org/0000-0002-9893-173X, Brandão H https://orcid.org/0000-0001-90617749, Druzian JI https://orcid.org/0000-0001-8940-6098, Conceição AS https://orcid.org/0000-0002-8800-422X, Lopes MV https://orcid.org/0000-0001-5985-8755, Figueiredo CA https://orcid.org/0000-0003-1356-6188

Citation/Cómo citar este artículo: Pinto LC, Souza CO, Souza SA, Silva HB, Silva RR, Cerqueira-Lima AT, Teixeira TO, Silva TMS, Medeiros KCP, Bittencourt M, Brandão HR, Druzian JI, Conceição AS, Lopes MV, Figueiredo CA. 2108. Potential of Annona muricata L. seed oil: phytochemical and nutritional characterization associated with nontoxicity. Grasas Aceites 69 (1), e234. https://doi.org/10.3989/gya.0777171

Copyright: (C2018 CSIC. This is an open-access article distributed under the terms of the Creative Commons Attribution 4.0 International (CC BY 4.0) License. 


\section{INTRODUCTION}

Annona muricata L., known as Soursop fruit, is native to America and has recently been aclimatized and established in many continents such as America, Africa and Asia (Nogueira et al., 2005). A. muricata has a history of popular use over the past few years and has been extensively described in the scientific literature as possessing biological properties such as analgesic and anti-inflammatory (Ishola et al., 2014), antidiabetic and antioxidant (Florence et al., 2014). Due to the presence of acetogenins, Annona has anti-tumor and apoptosisinducing properties (Moghadamtousi et al., 2015).

The soursop fruit and other parts of the plant are considered to be underutilized. One fruit may contain more than 200 seeds, which means the disposal of a large amount of seeds. The main countries which produce soursop are Brazil, Venezuela and Colombia. Bahia, Brazil is considered the world's largest producer of soursop and produces about 8,000 tons of fruit per year. It is used in processing industries in the production of fruit juices and pulps (ADAB, 2015), which results in large amount of seeds that are discarded and non-utilized commercially. The unused structures of the plant, seeds for example, can be a source of herbal products, bio-compounds and pharmaceutical ingredients. However, information on the composition, nutritional value and medicinal uses of the $A$. muricata seeds is still limited. Anuragi et al., (2016) report that the graviola seed is rich in oil and can be exploited in the oil industy. Elagbar et al., (2016) identified important fatty acids in the oil of $A$. muricata seeds and emphasized that this oil can be exploited for industrial, cosmetic, and medicinal purposes.

The characterization of the functional quality of A. muricata seeds may favor their use in the human diet, especially as a functional food. Such products are commonly known to contain bioactive compounds with properties that prevent degenerative diseases and other morbidities. Typically, anti-inflammatory and antioxidant properties exerted by medicinal plants are attributed different fatty acids, phenolic compounds (Dimitrios, 2006), alkaloids or other bioactive compounds, which are present in plant extract and oil. However, natural compounds can have toxic effects and interfere in the vegetable's consumption.

Given the above, the aim of this study was to evaluate the nutritional quality of A. muricata seeds and its oil through the chemical composition, quantification of phenolic compounds, antioxidant activity in vitro and toxicological evaluation in vivo.

\section{MATERIALS AND METHODS}

\subsection{Sample preparation}

The seeds were kindly provided in two batches (sample 1 and 2), by a of fruit pulp industry located in Ilhéus, Southern Bahia, Brazil. The seeds were identified and registered in the Herbarium of the State University of Bahia - Paulo Afonso HUNEBCollection $\left(n^{\circ} 28720\right)$.

The seeds were separated for grinding manually, subjected to crushing, and stored at $-20^{\circ} \mathrm{C}$ until analysis of composition. Before crushing, the seeds used for oil extraction were previously lyophilized to facilitate crushing and better extraction of ethereal components,

\subsection{Oil Extraction}

Oil extraction was performed according to BligDyer (1959) using methanol and chloroform as solvents. The decanted phase in the extraction process was collected and concentrated in a rota-evaporator equipment at $30 \mathrm{rpm}$ under vacuum $(695 \mathrm{mmHg})$ at $50-55^{\circ} \mathrm{C}$ for 45 minutes, and was then subjected to a final drying by means of direct contact with nitrogen gas to enable the volatilization of residual solvent and the precipitation of the crude oil ( $\mathrm{AmPtO}$ ). The oil was centrifuged at $2300 \mathrm{~g} / 5 \mathrm{~min}(4$ $\left.{ }^{\circ} \mathrm{C}\right)$ to separate precipitated lipids and for obtaining the supernatant oil $(\mathrm{AmSO})$. The patent for this extraction process was deposited at the Intellectual Property Institute (INPI) (BR102016029177-1).

\subsection{Centesimal composition}

Centesimal composition was performed on fresh samples, in triplicate, and the determination of lipids, proteins, dietary fiber, moisture and ash was performed according to the analytical method of the Adolfo Lutz Institute (2008). The quantification of carbohydrates was performed by percentage differences in comparison to other components.

\subsection{Quantification of phenolic compounds}

The Folin and Ciocalteu assay was used for the quantification of total phenolic compounds using gallic acid as a standard in lyophilized seeds (Instituto Adolfo Lutz, 2008). Aqueous and methanolic extracts in the sample were analyzed in a concentration of $0.5 \mathrm{mg} \cdot \mathrm{mL}^{-1}$ in a spectrophotometer VIS/UV at $760 \mathrm{~nm}$. A standard curve was plotted using gallic acid $\left(0\right.$ to $\left.8 \mathrm{mg} \cdot \mathrm{mL}^{-1}\right)$. The results were expressed as milligram of tannic acid (ETA) and gallic acid (EGA) equivalents per gram of the dry weight sample.

\subsection{In vitro antioxidant activity}

An $A m S O$ extract was made by adding the oil $(0.5 \mathrm{~g})$ to a methanol solution $(50 \%)$, and after one hour of incubation at room temperature $\left(28 \pm 1^{\circ} \mathrm{C}\right)$, acetonic solution $(70 \%)$ was added, followed by distilled water to a final volume of $100 \mathrm{~mL}$ (Rufino et al., 2007). DPPH (2,2-diphenyl-1-picrylhydrazyl) free radical scavenging assay was made as per 
Roesler et al. (2007) to obtain the final result, which is expressed in $\mathrm{IC}_{50}$ (g sample/g DPPH). The $A B T S$ [2,2'-azino-bis(3-ethylbenzothiazoline-6-sulphonic acid)] method was used with standard Trolox and UV/ VIS at 734nm (Rufino et al., 2006). A ferric reducing antioxidant potential (FRAP) assay was made using the standard ferrous sulphate and spectrophotometer VIS/UV at 595nm (Rufino et al., 2006).

\subsection{Fatty acid profile}

Fatty acids profile was determined by the capillary column gas chromatographic method applied to the oil methyl esters. The amount of total fatty acids (sum of free and bound fatty acids) in the oil was obtained by transesterification into the corresponding methyl esters (fatty acid methyl esters (FAME)), through saponification with $\mathrm{NaOH}(0.5 \mathrm{~N})$ in methanol, followed by methylation with a solution of boron trifluoride $\left(\mathrm{BF}_{3}\right)$ catalyst (12\% in methanol). The FAME were extracted with iso-octane and stored in an inert atmosphere $\left(\mathrm{N}_{2}\right)$ in the freezer at $-18^{\circ} \mathrm{C}$. The FAME separation was performed on a gas chromatograph (Varian $^{\circledR}$ 3800 ) equipped with a flame ionization detector and a fused silica capillary column Elite-WAX $(30 \mathrm{~m} \times 0.32$ $\mathrm{mm} \times 0.25 \mathrm{~mm}$ ). The analysis parameters were: injector temperature of $250{ }^{\circ} \mathrm{C}$ and detector temperature of $280^{\circ} \mathrm{C}$. The following thermal program was used: $150^{\circ} \mathrm{C}$ for $16 \mathrm{~min}$, then increased by $2^{\circ} \mathrm{C} \cdot \mathrm{min}^{-1}$ up to $180{ }^{\circ} \mathrm{C}$, held for $25 \mathrm{~min}$, followed by an increase of $5^{\circ} \mathrm{C} \cdot \mathrm{min}^{-1}$ up to $210^{\circ} \mathrm{C}$, held for $25 \mathrm{~min}$. Helium was used as carrier gas at $1.3 \mathrm{~mL} \cdot \mathrm{min}^{-1}$. Nitrogen gas was used as make up gas $\left(30 \mathrm{~mL} \cdot \mathrm{min}^{-1}\right)$; the flow of hydrogen gas and air were provided at 30 and at 300 $\mathrm{mL} \cdot \mathrm{min}^{-1}$, respectively. The injections were performed in duplicate for each extraction in a volume of $1 \mu \mathrm{L}$.

The FAME were identified by comparing retention times with known mixed standards (189-191AMP FAME Mix C4-C24; Sigma-Aldrich $\left.{ }^{\circledR}\right)$. The quantification of fatty acids, expressed in milligrams per gram of lipids, was performed by adding internal standard (C23:0 Sigma ${ }^{\circledR}$, USA) and calcuated using equation 1. Reported yields were averaged from duplicate extractions (Nascimento et al., 2003):

Concentration $\left(m g \cdot g^{-1}\right)=\left(A_{x} x W_{i s} x C F_{x}\right) /=\left(A_{i s} x\right.$ $\left.W_{s} \times C F_{s}\right) \times 1000$

Where: $A_{x}$ Area of methyl ester fatty acid peek in the chromatogram of the sample.

$\mathrm{W}_{\text {is }}$ Weight (in milligrams) of internal standard added to the sample.

$\mathrm{CF}_{\mathrm{s}}$ Conversion factor of fatty acid methyl ester to fatty acid.

$\mathrm{A}_{\mathrm{is}}$ Area of internal standard methyl ester of fatty acid peek in the chromatogram of the sample.

$\mathrm{W}_{\mathrm{s}}$ Sample weight (in milligrams).

$\mathrm{CF}_{\mathrm{x}}$ Correction factor response of each fatty acid methyl ester ionization detector, relative to 23:0

\subsection{Physiochemical screening of crude oil}

The AmPtO sample was separated as precipitate (solid residue in low temperature) and $A m S O$ (supernatant oil). AmPtO $(50 \mathrm{mg})$ was dissolved in methanol and acetonitrile (1:1) and extracted in solid phase extraction (SPE). A Sep-Pak silica cartridge (Waters) was sequentially conditioned with $5 \mathrm{~mL}$ of hexane and $5 \mathrm{~mL}$ dichloromethane to prevent the cartridge from drying. AmPtO was passed through the cartridge and eluted with 10 $\mathrm{mL}$ of dichloromethane, ethyl acetate and methanol. The eluates were dried under reduced pressure in a rotatory evaporator at $40{ }^{\circ} \mathrm{C}$ to yield $14.0 \mathrm{mg}$ dichloromethane, $13.5 \mathrm{mg}$ ethyl acetate and $8.0 \mathrm{mg}$ of methanol fractions. After evaporating to dryness by rotary evaporator, the residues were dissolved in methanol and acetonitrile, filtered through a 0.45 $\mu \mathrm{m}$ nylon syringe filter (Whatman) and injected into the HPLC system. The standard stock and working solutions were stored at $4{ }^{\circ} \mathrm{C}$.

All reagents used were of analytical grade. HPLC-grade methanol and acetonitrile were purchased from Tedia and Merck, respectively. The deionized water was purified using a Milli-Q system (Millipore, Milford, MA, USA).

The thin layer chromatographic profiles were made with $A m S O, A m P t O$ and their fractions obtained by SPE extraction according to Grzybowski et al., (2012). Chromatoplates were made with hexane: chloroform: nitroethane: ethyl acetate: acetone: methanol: acetonitrile: water (12:2:4:4:1:2:1.6:0.1, $\mathrm{v} / \mathrm{v})$ as mobile phase. The spray for acetogenin constituents was specifically Kedde's reagent (alkalinized 3,5-dinitrobenzoic acid).

HPLC was performed in a Shimadzu Prominence LC-20AT equipped with a (SPD-M20) diode array detector (HPLC-DAD) (Shimadzu Corp. Kyoto, Japan). The samples were injected into a Rheodyne $7125 \mathrm{i}$ injector with a $50 \mu \mathrm{L}$ loop. The column heater was set at $30{ }^{\circ} \mathrm{C}$. The chromatographic separation was performed with a Luna Phenomenex C-18 column ( $250 \mathrm{~mm}$ x $4.6 \mathrm{~mm}$ x $5 \mu \mathrm{m}$, Phenomenex). The compounds were separated using a mobile phase consisting of water (A) and acetonitrile:methanol $(1: 1, \mathrm{~B})$. The separation gradient was: $0-20 \mathrm{~min}$ $70-100 \%$ B, $20-40 \min 100 \%, 45$ min stop at a flow rate of $1.0 \mathrm{~mL} \cdot \mathrm{min}^{-1}$. A $50 \mu \mathrm{L}$ sample was injected and the detection of compounds was performed using light with a wavelength of $215 \mathrm{~nm}$. The infrared absorption spectra were recorded in $\mathrm{KBr}$ pellets using a Varian 640 FT-IR spectrophotometer with a PIKE ATR accessory operating in the 4000-400 $\mathrm{cm}^{-1}$ range. Liquid chromatograph Electrospray ion source mass spectrometer (LC-ESI-MS) was obtained in negative electrospray mode using an Esquire 3000 Plus instrument (Bruker). Thin-layer chromatography plates were run using $60 \mathrm{~F}_{254}$ silica gel (Macherey-Nagel). 


\subsection{In vivo toxicity evaluation}

\subsubsection{Animals and ethical considerations}

BALB/C mice of 8-10 weeks old were used in this study. The animals were housed at $22{ }^{\circ} \mathrm{C}$ and received water and food ad libitum until the time of the experiment. Animal procedures were performed in accordance with the recommendations of the Ethics Committee of the Institute of Health- Federal University of Bahia Sciences (CEUA/ICS 029/2012).

\subsubsection{Experimental protocols}

The experimental protocol aimed to verify the toxicity of repeated doses (ANVISA, 2010) of 14 days-exposure daily to AmPtO and $\mathrm{AmSO}$ doses was $0.5 \mathrm{~mL} \cdot \mathrm{Kg}^{-1}$ animal weight and 1.0 $\mathrm{mL} \cdot \mathrm{Kg}^{-1}$ animal weight, respectively. The oil samples were diluted in saline and emulsified using DMSO (dimethylsulfoxide, 0.5\%, Sigma). The animals were divided into three groups, each group with 6 animals. On day 14 (D14), the animals were euthanized $\left(150 \mathrm{mg} \cdot \mathrm{Kg}^{-1}\right)$ thiopental associated with $10 \mathrm{mg} \cdot \mathrm{Kg}^{-1}$ lidocaine) and histopathological and biochemical samples were taken for the analysis of toxicity.

AmPtO protocol groups were defined as follows: the CtrlAmPtO group (control): received saline orally $(200 \mu \mathrm{L}$ of saline + DMSO $0.5 \%)$; the AmPtO0.5 group received crude oil orally at 0.5 $\mathrm{mL} \cdot \mathrm{kg}^{-1}$ (oil diluted in $200 \mu \mathrm{L}$ of saline + DMSO $0.5 \%)$; the AmPtO1.0 group received crude oil orally at $1.0 \mathrm{~mL} / \mathrm{kg}$ (oil diluted in $200 \mu \mathrm{L}$ of saline + DMSO 0.5\%).

The $A m S O$ protocol was followed with the same oil doses $\left(0.5 \mathrm{~mL} \cdot \mathrm{kg}^{-1}\right.$ and $\left.1.0 \mathrm{~mL} \cdot \mathrm{kg}^{-1}\right)$ and the groups were defined as $C \operatorname{trl} A m S O$ group; $A m S O 0.5$ group; $A m S O 1.0$ group. $A m S O$ was dissolved in saline followed by filtration $(0.2 \mu \mathrm{m})$. The filtration process allowed separating the precipitate in the crude oil of the supernatant liquid fraction $(A m S O)$. The waste precipitates were retained in the filter, thus, a quantity of $40 \%$ of $\mathrm{AmSO}$ weight was added to correct the average percentage weight loss during filtration.

\subsubsection{Histopathological, physical, biochemical and haematological analysis}

The animals were weighed on D1 and D14 of the protocol. On D14, before euthanasia, three independent observers trained in animal experiments evaluated the overall appearance of the animals, according to the score of toxicity signs: (0) normal appearance and coat; (1) discrete change in coat and discrete cachexia; (2) coat change and cachexia (Lerco et al., 2003). Liver and spleen were collected for weight evaluation. The ratio of liver weight/body weight of the animal was calculated to identify liver relative weight (Ritter et al., 2012).

Liver and kidney samples were paraffin embedded twice after fixing with $10 \%$ formalin using a microtome; the paraffin blocks were cut into serial $3 \mu \mathrm{M}$ sections. In the staining step, the slides were immersed in hematoxylin-eosin (HE). Histopathological changes were evaluated by two different pathologists, blindly.

Blood glucose levels, total cholesterol, urea and creatinine were performed in semi-automatic Bioplus 2000 equipment using commercial kits (Doles) according to the manufacturer. The quantitation of leukocytes was performed by manual counting, with dilution in Turk liquid $(200 \mu \mathrm{L}$ liquid Turk $+20 \mu \mathrm{L}$ of blood with Ethylenedeamine Tetra Acetic Acid (EDTA)).

\subsection{Statistical analysis}

One-way analysis (ANOVA) and Tukey Test correction to post-test (for data with normal distribution) and Kruskal Wallis and Dunn as post-test (for data without normal distribution) were used to determine statistical significance among groups using GraphPad V5 (GraphPad Software Inc., San Diego, CA, USA) software. The results were considered significant when $\mathrm{p}<0.05$.

\section{RESULTS}

\subsection{Centesimal composition, phenolic compounds and in vitro antioxidant activity}

The results of centesimal composition (wt \%) of A. muricata seeds in natura were: moisture $34.7 \pm 0.02$; ash $1.3 \pm 0.01$; proteins $9.85 \pm 0.31$; lipids $18.3 \pm 0.28$; fibers $24.7 \pm 0.52$ and carbohydrates 11.15. The polyphenols of aqueous extracts in the A. muricata lyophilized seeds showed a variation of $310-320 \mathrm{mg} \%$, which is $3.2 \pm 0.02 \mathrm{mg}$ TAE/g and 3.1 $\pm 0.02 \mathrm{mg} \mathrm{GAE} / \mathrm{g}$ (tannic acid and gallic acid equivalents, respectively). Methanol extracts showed turbidity, making them impossible to read in the spectrophotometer.

The In vitro antioxidant capacity, AmSO showed $370133.0 \mu \mathrm{g} \cdot \mathrm{mL}^{-1}$ DPPH (DPPH assay); $40.2 \mu \mathrm{mol}$ trolox/g (ABTS assay) and $50.7 \mu \mathrm{mol}$ $\mathrm{Fe}_{2} \mathrm{SO}_{4} \cdot \mathrm{g}^{-1}$ (FRAP assay). Regarding the DPPH assay, the lowest value of the sample, able to reduce DPPH by $50 \%\left(\mathrm{IC}_{50}\right)$, had better antioxidant activity. The assessment of the ABTS and FRAP methods in a better antioxidant activity was based on the higher amount of equivalent in trolox or ferrous sulfate per gram of sample, respectively. Overall, in comparison with standard gallic acid $\left(1.30 \mu \mathrm{g} \cdot \mathrm{mL}^{-1} \mathrm{DPPH} ; 18.917 .0 \mu \mathrm{mol}\right.$ trolox/g; 41946.7 $\left.\mu \mathrm{mol} \mathrm{Fe}_{2} \mathrm{SO}_{4} \cdot \mathrm{g}^{-1}\right), \mathrm{AmSO}$ had low antioxidant activity. 


\subsection{Fatty acid profile}

A. muricata seed oil had a total of $75 \%$ unsaturated fatty acids (Table 1). The fatty acid profile of the two oil samples analyzed, each in duplicate, were similar. Considering the percentage of unsaturated fatty acids, $40 \%$ was monounsaturated, represented by $39.2 \%$ oleic acid (n-9). The second highest detected percentage $(33 \%)$ of fatty acid was linoleic $(n-6)$. The oil contained a low content of $\alpha$-linolenic acid (n-3). Regarding the saturated content $(24.5 \%)$, the most representative fatty acid was palmitic (19.3\%).

\subsection{Phytochemical screening}

Figure 1-A shows the chromatographic profile in chromatoplate of the oil, precipitate and the fractions obtained by SPE extraction. This clearly revealed predominant rose-wine coloration spots (positive Kedde's reaction) on the acetogenin family members (Figure 1-A). The absorption in the UV spectrum at $215 \mathrm{~nm}$ was observed in HPLC-DAD analyses (Figure 1-B and 1-C). The presence of acetogenins was confirmed by the LC-ESI-MS analysis, which detected several peaks with molecular weights ( $\mathrm{m} / \mathrm{z}$ values), which are typical of these compounds. In all the samples, the most abundant peaks corresponded to the molecular weight corresponding to annonacin $\left(\mathrm{C}_{35} \mathrm{H}_{64} \mathrm{O}_{7}\right.$; mol. wt. $\left.595[\mathrm{M}-\mathrm{H}]^{-}\right)$. Fractionation of the extract (precipitate residue) by SPE allowed the observation of the major acetogenin (Figure 1-B and 1-C), which was confirmed to be annonacin $\left(\mathrm{m} / \mathrm{z} 595,[\mathrm{M}-\mathrm{H}]^{-}\right.$, mainly in the methanol fraction (Figure 1-D).

\subsection{In vivo toxicity}

\subsubsection{Survival}

In the AmPtO protocol, the AmPtOl.0 group showed an important reduction in survival in the early days of the Protocol and reached a percentage lower than 50\%. In the AmSO protocol, all the animals showed $100 \%$ survival.

\subsubsection{Physical, biochemical and haematological analysis}

Table 2 shows the biochemical and physical parameters of in vivo experiments. The AmPtO1.0 group showed a statistical difference in blood glucose level compared to the $\mathrm{CtrlAmPtO}$ group and AmPtO0.5 group $(\mathrm{p}<0.001$ and $\mathrm{p}<0.01$, respectively). The AmPtO1.0 group also showed weight loss (variable average $-1.3 \mathrm{~g}$ ) compared to the other experimental groups. The AmPtO0.5 group was characterized by moderate signs of toxicity (score 1) and the AmPtO1.0 group showed more intense toxicity signs (score 2). In the AmSO protocol, liver weight was inversely proportional to oil doses ( $\mathrm{p}<0.01$ and $\mathrm{p}<0.001$, respectively for AmSO0.5 and $A m S O 1.0$ ) in comparison to the control group (CtrlAmSO) and was evidenced by liver relative weight (ratio of 0.027 ) in relation to body weight.

TABLE 1. Fatty acid profiles in Annona muricata L. seed oils

\begin{tabular}{|c|c|c|c|c|c|c|c|}
\hline \multirow[b]{2}{*}{ Fatty acids } & \multirow[b]{2}{*}{ Name } & \multicolumn{2}{|c|}{ Sample 1} & \multicolumn{2}{|c|}{ Sample 2} & \multicolumn{2}{|c|}{ Sample 1 and 2} \\
\hline & & mgFA/g fat & $\operatorname{mgFA} \%$ & mgFA/g fat & mgFA \% & $\begin{array}{c}\text { Average } \\
(\mathbf{m g ~ F A} \%)\end{array}$ & $\begin{array}{l}\text { Standard } \\
\text { deviation }\end{array}$ \\
\hline C16:0 & Palmitic & 128.72 & 17.78 & 150.80 & 20.83 & 19.31 & 2.16 \\
\hline $\mathrm{C} 16: \ln 7$ & Palmitoleic & 11.29 & 1.56 & 11.72 & 1.62 & 1.59 & 0.04 \\
\hline C18:0 & Steararic & 29.76 & 4.11 & 36.20 & 5.00 & 4.56 & 0.63 \\
\hline $\mathrm{C} 18: \ln 9 \epsilon$ & Oleic & 283.87 & 39.22 & 283.65 & 39.19 & 39.21 & 0.02 \\
\hline $\mathrm{C} 18: 2 \mathrm{n} 6 \epsilon$ & Linoleic & 250.53 & 34.61 & 227.00 & 31.36 & 32.99 & 2.30 \\
\hline $\mathrm{C} 18: 3 \mathrm{n} 3$ & $\alpha$-Linolenic & 9.21 & 1.27 & 8.70 & 1.20 & 1.24 & 0.05 \\
\hline C20:0 & Arachidonic & 3.26 & 0.45 & 3.91 & 0.54 & 0.50 & 0.06 \\
\hline C20:1n9 & Gadoleic & nd & nd & 0.95 & 0.13 & 0.07 & 0.09 \\
\hline C22:0 & Behenic & 1.09 & 0.15 & n.d. & n.d. & 0.08 & 0.11 \\
\hline C24:0 & Lignoceric & 1.19 & 0.17 & 0.91 & 0.13 & 0.15 & 0.03 \\
\hline$\Sigma$ Saturated & & 164.02 & 22.49 & 191.83 & 26.50 & 24.50 & 2.84 \\
\hline$\Sigma$ Unsaturated & & 554.9 & 76.66 & 532.01 & 73.50 & 75.08 & 2.23 \\
\hline$\Sigma$ Monounsaturated & & 295.19 & 40.78 & 296.32 & 40.94 & 40.86 & 0.11 \\
\hline$\Sigma$ Polyunsaturated & & 259.74 & 35.88 & 235.7 & 32.56 & 34.22 & 2.35 \\
\hline
\end{tabular}

FA: fatty acids. nd: not detected 


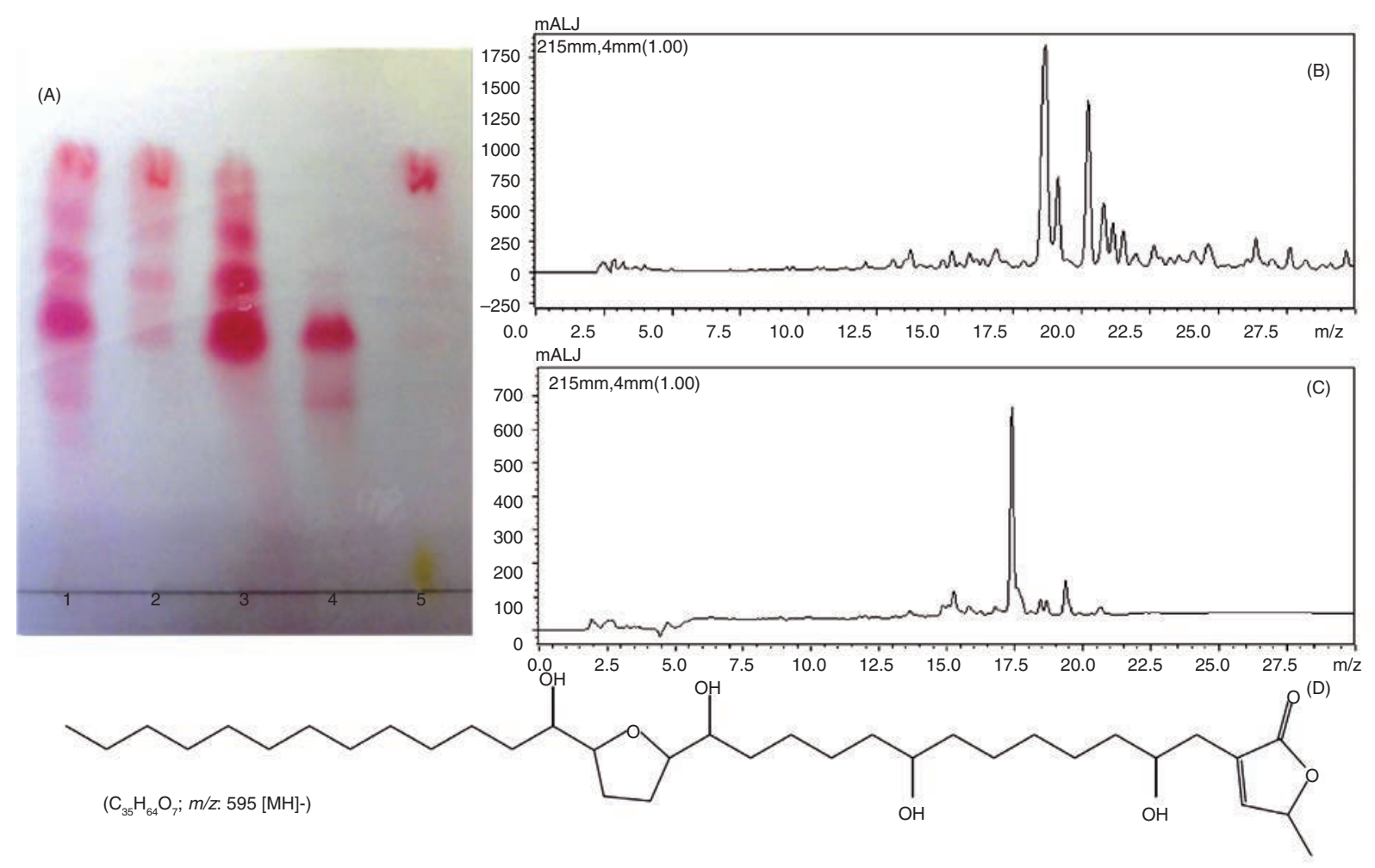

FIGURE 1. A) Thin layer chromatograph of extract and fractions from A. muricata seed oil. Spray with Kedde's reagent. Numbers 1: precipitate residue, 2: dichloromethane fraction; 3: ethyl acetate fraction; 4: methanol fraction and 5; oil extract. B and C) HPLCDAD chromatograms $(215 \mathrm{~nm})$ of precipitate residue (B) and methanol fraction (C) from A. muricata seeds oil. (D) Annonacin molecular structure.

\subsubsection{Histopathological analysis}

Figures $2(\mathrm{~A}, \mathrm{~B}, \mathrm{C})$ and $3(\mathrm{~A}, \mathrm{~B}, \mathrm{C})$ show the impact of toxicity in the liver tissue. In the AmPtO protocol, the CtrlAmPtO group showed preserved morphology with isomorphic hepatocytes arranged in cords, directed to the centrilobular hepatic veins and hepatic sinusoid, with thin walls with the frequent presence of Kupffer's cell. Portal spaces were regularly distributed and the typical polygonal morphology of hepatocytes and evident cell nucleus were observed. The hepatocytes of the AmPtO0.5 group and AmPtO1.0 group showed focal and minimal histological changes. The AmPtO0.5 and AmPtO1.0 groups showed discrete hepatic steatosis (Figure 2-B and 2-C, black circle). The liver section of the AmPtO0.5 group showed some hemorrhagic areas with necrosis (Figure 2-B, red arrow). Histopathological changes were not identified in the case of the AmSO protocol.

Figures $2(\mathrm{D}, \mathrm{E}, \mathrm{F})$ and $3(\mathrm{D}, \mathrm{E}, \mathrm{F})$ show the kidney histopathological analysis. The $\mathrm{CtrlAmPtO}$ group showed normal characteristics of the renal parenchyma. Magnification at 100x revealed an eosinophilic cortex with the abundance of proximal convoluted tubules along with well distributed and uniform renal corpuscles. Magnification at 400x allowed for the observation of glomeruli with Bowman's capsule and capillary tube supported by delicate mesangium, discarding features of glomerulonephritis (Figure 2-D). The abundant proximal convoluted tubules had preserved cubic epithelium and strongly eosinophilic cytoplasm which differed from the distal convoluted tubules. The AmPtO0.5 group had similar characteristics, however, the glomeruli showed discrete atrophy and restricted Bowman's space (Figure 2-E, white arrow), and the presence of capillary hyperemia in the medullary area between the collecting tubules. The AmPtO1.0 group had some tubules with more eosinophilic cytoplasm, the presence of precipitates, more basophilic cell nucleus associated with karyolysis and coagulative necrosis (Figure 2-F, asterisk). In the $A m S O$ protocol (Figure 3) similar morphological characteristics in the cortical area, glomeruli with proportional size, the presence of a capsule and Bowmn's space, simple cubic and upright tubular epithelium were observed. In the medullary zone, the tubules' normal collectors between the various blood capillaries, with low columnar cubic epithelium with visible lumen were also observed. 


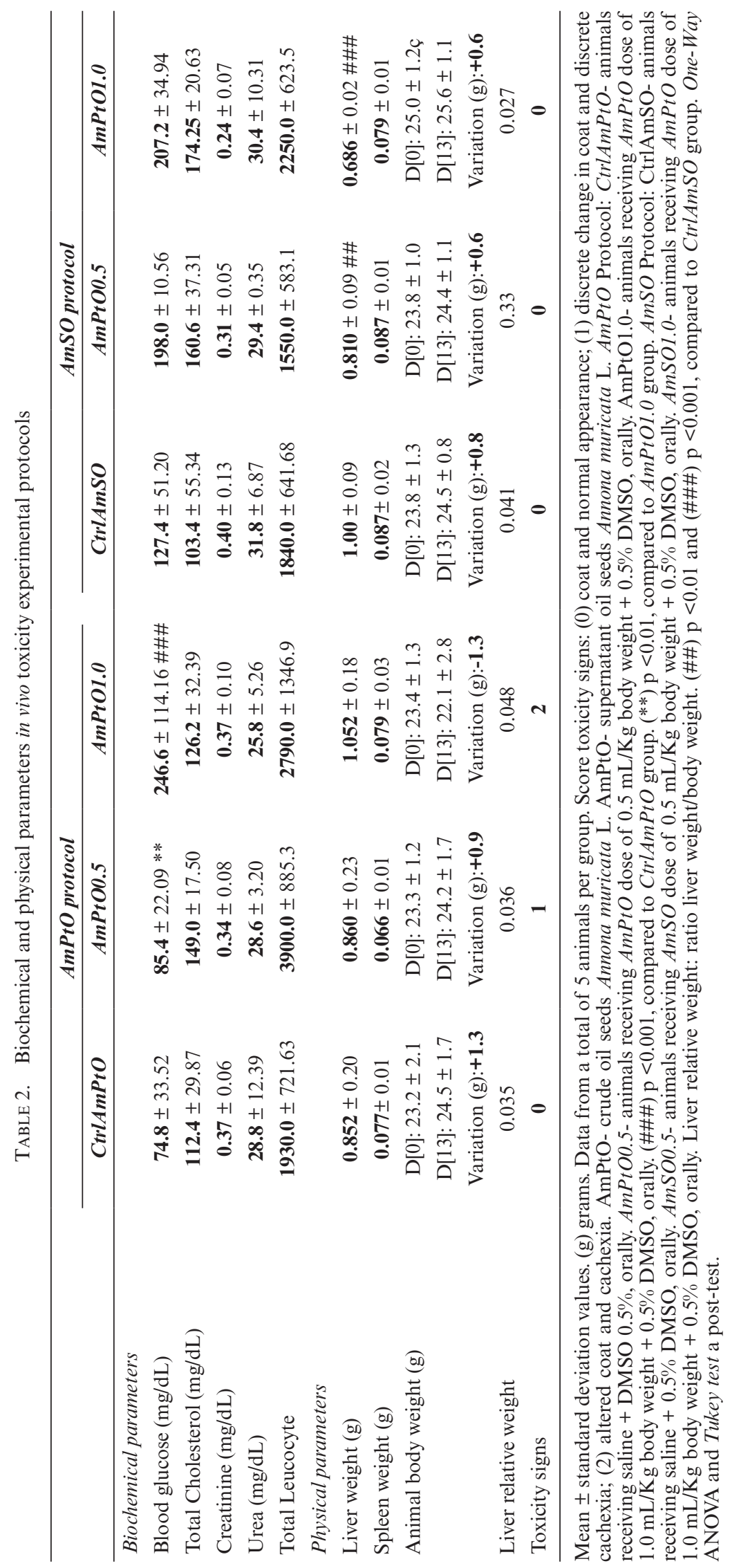


(a)

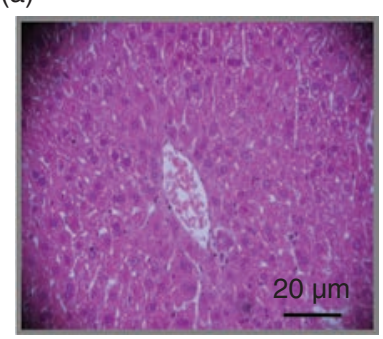

(d)

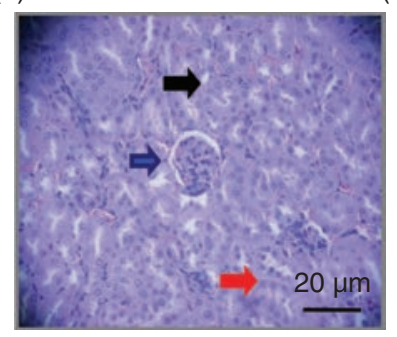

(b)

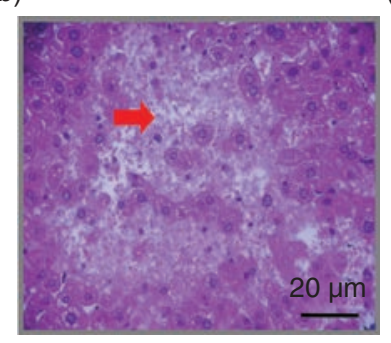

(c)

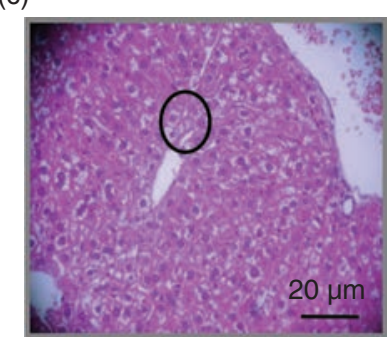

(f)

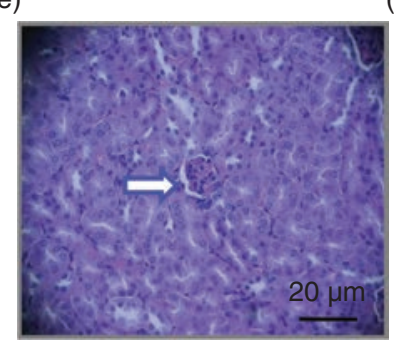

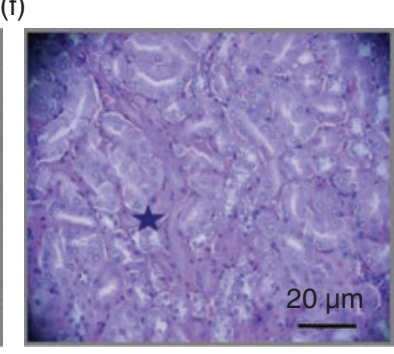

Figure 2. Liver and kidney histopathology AmPtO protocol in vivo toxicity. AmPtO- crude oil seeds Annona muricata L. (A, D) CtrlAmPtO group- animals receiving saline $+0.5 \%$ DMSO, orally. (B, E) AmPtO0.5 group- animals receiving AmPtO dose of $0.5 \mathrm{~mL} / \mathrm{Kg}$ body weight $+0.5 \%$ DMSO, orally. (C, F) AmPtO1.0 group- animals receiving AmPtO dose of $1.0 \mathrm{~mL} / \mathrm{Kg}$ body weight + $0.5 \%$ DMSO, orally. (B) Arrow: hemorrhagic area and necrosis. (C) Circle: hepatic steatosis. (D) Black Arrow: proximal convoluted tubule. Blue arrow: glomerulus. Gray arrow: distal convoluted tubule. (E) White arrow: glomerulus atrophied. (F) Asterisk: karyolysis

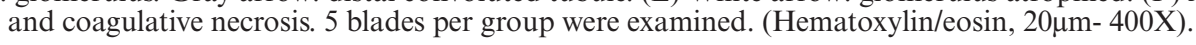

\section{DISCUSSION}

A. muricata L. seeds have potential for use in human and animal diets, provided they are not toxic. Fasakin et al., (2008) also evaluated the composition of the seeds of soursop fruit from Nigeria, and identified a high content of oil and protein, which were low in toxins (tannins, phytate, and cyanide). These authors identified $22.57 \%$ lipids in the seed, and a total of $27.34 \%$ protein, which is higher than in the current study. These variations may due to the climatic and edaphic conditions in which the plants were grown (Marineli et al., 2004). Therefore, it is important to characterize the fruits in different regions and countries. Elagbar et al., (2016) identified $21.5 \%$ of lipids in A. muricata seeds' crude fixed oil on a dry weight basis. In the crude oil of the present study, a total of $18.3 \%$ lipids were identified in the in natura samples. Considering the presence of moisture $(34.7 \%)$, it is probable that our seed sample had a higher yield of lipids and greater potential for oil extraction. Santos et al., (2014) evaluated total phenolic compounds in four varieties of Annona cherimola, of Portuguese origin, and found values lower than $0.05 \mathrm{mg} \cdot \mathrm{g}^{-1}$ of seed sample. In the current study, $A$. muricata seeds had a total of approximately $0.31 \mathrm{mg} \cdot \mathrm{g}^{-1}$ of phenolics, hence, they can be considered a moderate source of phenolic compounds.

The Seed oil showed low antioxidant activity in vitro. Vegetable oils have a considerable content in tocopherols, which are potential antioxidants (Guinazi et al., 2009). It is probable that $A$. muricata seeds oil can naturally have low antioxidant compounds or such compounds may be lost in the oil extraction process.

Despite the low antioxidant activity identified in the seeds, leaf extracts of the A. muricata are well characterized in the literature as having antioxidant properties. Lee et al., (2014) evaluated the antioxidant activity and components in dry extracts of the A. muricata leaves and reported DPPH $\mathrm{IC}_{50}$ at $98.9 \pm 9.1 \mathrm{mg} / \mathrm{mg}$ extract, and the total content of phenolics to be $86.5 \pm 14.8 \mathrm{mg} \mathrm{GAE} / \mathrm{g}$ extract. Leaf extracts of A. muricata were identified as a rich source of antioxidant components such as carotenoids.

The high lipid content also enhances the use of A. muricata seeds or the production of pharmaceutical and industrial oils. The most representative fatty acids in the oil analyzed were oleic and linoleic, which are well characterized and imply benefits for cardiovascular health and a reduced risk of metabolic syndrome (Mayneris-Perxachs et al., 2014). Elagbar et al. (2016) identified fourteen fatty acids in the fixed oil of A. muricata seeds extracted using hexane or diethylether and found a total of approximately $23 \%$ saturated, $40 \%$ monounsaturated and $36 \%$ polyunsaturated. In this study, oleic $(39 \%)$ and linoleic $(35 \%)$ acids were the main fatty acids identified. The results were similar to our study, despite the different methods of oil extraction.

Some studies suggest that in addition to the benefits of the fatty acids present in vegetable oils, the presence of minor components which are contained in the natural source of the oil act synergistically, 
(a)

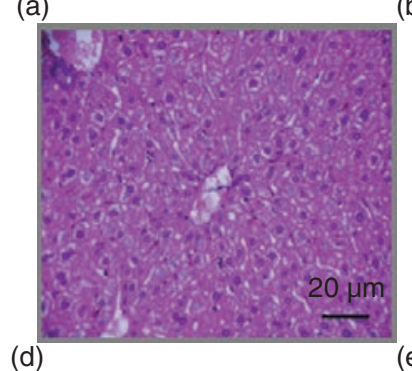

(d)

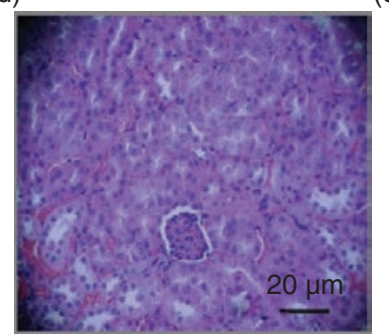

(b)

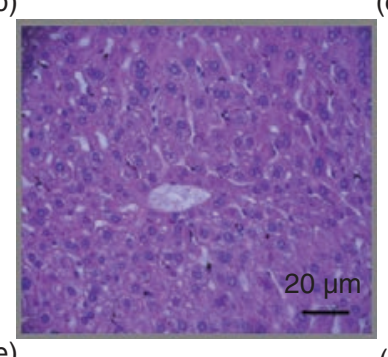

(c)

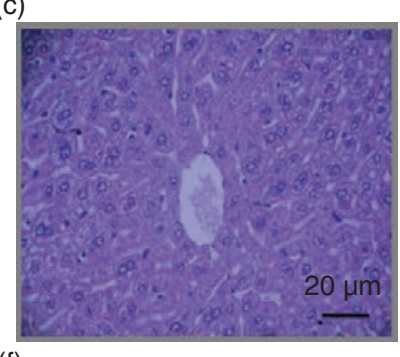

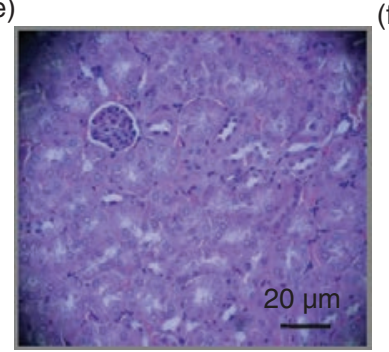

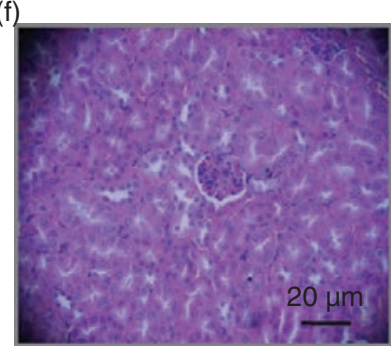

FiguRE 3. Liver and kidney histopathology $A m S O$ protocol in vivo toxicity. AmSO-supernatant oil seeds Annona muricata L. (A, D) CtrlAmSO group- animals receiving saline + 0.5\% DMSO, orally. (B, E) AmSO0.5 group- animals receiving AmSO dose of $0.5 \mathrm{~mL} / \mathrm{Kg}$ body weight $+0.5 \%$ DMSO, orally. (C, F) AmSO1.0 group- animals receiving AmSO dose of $1.0 \mathrm{~mL} / \mathrm{Kg}$ body weight + $0.5 \%$ DMSO, orally. 5 blades per group were examined. (Hematoxylin/eosin, $20 \mu \mathrm{m}-400 \mathrm{X}$ ).

favoring the inherent functional properties, for example in Chilean chia oil (Marineli et al., 2014). Some alkaloids have been identified in A. muricata such as anonina, muricina and muricinina (Franzão and Melo, 2007) and acetogenins (Moghadamtousi et al., 2015). Acetogenins are derived from long chain fatty acids (C35 and C39) and are found specifically in the Annonaceae family and have antitumor activity and apoptosis-inducing activity (Moghadamtousi et al., 2015). Thus, it is important to identify the bioactive compounds in vegetable oils which have functional and pharmacological properties.

Alkaloids were not found in $\mathrm{AmSO}$ or $\mathrm{AmPtO}$ (data not shown). The principal spot was present in all the samples analyzed in the present study, mainly in the methanol fraction, and may be associated to the presence of annonacin, considering that acetogenin is the major compound in A. muricata seeds (Moghadamtousi et al., 2015; Grzybowski et al., 2012; Champy et al., 2002). The strong absorption at $1745 \mathrm{~cm}^{-1}$ (lactone $\mathrm{C}=\mathrm{O}$ ), a strong aliphatic $\mathrm{C}-\mathrm{H}$ absorption below $3000 \mathrm{~cm}^{-1}$ in the IR spectrum suggested the presence of an unsaturated lactone moiety in an annonacin-type acetogenin (Champy et al., 2002). Le Ven et al., (2012) identified anonacin as the main acetogenin in extracts of the manufactured $A$. muricata nectar. In this study, the authors identified nine compounds of Fragmentation of $\mathrm{m} / \mathrm{z}$ $603.4797([\mathrm{C} 35 \mathrm{H} 64 \mathrm{O} 7 \mathrm{Li}]+)$, which corresponds to the isomers of annonacin.

Champy et al., (2002) analyzed annonacin in extracts obtained from A. muricata. In all preparations, fruit pulp, nectar, infusions and decoctions of leaves, the quantification showed that annonacin represented approximately $70 \%$ of all acetogenins. The analysis in the present study showed that A. muricata seed extracts and oil contained acetogenins and annonacin was the major compound. Annonacin was characterized by its neurotoxic properties and as an inhibitor of mitochondrial complex I (Yu et al., 1992; De Pedro et al., 2013). However, acetogenins can be related to the etiology of neurodegenerative diseases, such as Guadeloupean atypical Parkinsonism and perturbations in the protein Tau due to depletion ATP supply and interrupt the transport of mitochondria to the sum of neural cells (Yu et al., 1992). The pharmacokinetic mechanisms of annonacin are still to be known.

The mechanical filtration process enabled a reduction in the presence of acetogenin, as shown in Figure 1-A. Other methods may be implemented to reduce toxic components, and thereby facilitate the use of $A$. muricata seed oil in the human diet.

Acute exposure to different doses of seed oil ( $A m P t O$ and $A m S O$ ) was performed for assessing toxicological effects. The process of oil filtration was important to differentiate the protocols, with crude oil (with precipitate) and liquid oil (oil supernatant). The survival rate of less than $50 \%$ in the AmPtO1.0 group was high and implies considerable toxic effects of crude oil. In $A m S O$ protocols, the AmSO0.5 and AmSO1.0 groups received filtered oil and remained alive throughout the experiment, suggesting that the mortality identified in the AmPtO1.0 group was linked to the precipitated consumption in the oil, which was depleted after filtration. 
Some biochemical and physical parameters evaluated confirmed the toxic effect of the crude oil ( AmPtO). The AmPtO1.0 group showed increased blood glucose, a negative weight variable, toxicity signs and histopathological changes in hepatic and renal tissue (Table 2 and Figures 2 and 3). Animal groups that received $A m S O$ showed no toxicity signs or histopathological changes, which indicates that the precipitate in $\mathrm{AmPtO}$ may be related to the toxicity observed in this group. This can probably be associated to the presence of acetogenins, more concentrated in the crude oil and its fractions (Figure 2).

Acetogenins, especially annonacin, act as mitochondrial complex I inhibitors and are implicated in neurological disturbances, arising from the decreased ATP available to neural cells ( $\mathrm{Yu}$ et al., 1992; De Pedro et al., 2013). The mitochondrial respiratory chain can be separated into 4 enzyme complexes, with complex I representing the NADH-ubiquinone reductase. This enzyme plays a crucial role in the generation of ATP and its role in the performance of neurodegenerative diseases has been considered (Schapira, 2010). The hepatotoxic and nephrotoxic effects in the AmPtO consumption identified in this study may also be associated with the inhibitory action of the mitochondrial enzyme complex in these specific organs.

$A m S O$ showed nutritional quality and no toxicity. However, a reduction in the liver weight of the AmSO0.5 and AmSO1.0 groups compared to CtrlAmSO group was observed (Table 2). The hepatoprotective effect has been identified in coconut oil, the study of Zakaria et al., (2011). Treatment with virgin coconut oil reduced the hepatotoxicity induced by acetaminophen, reduced the dosages of liver enzymes and improved liver morphology. A reduction in the levels of creatinine also was observed in the AmSO1.0 group in compared to $C \operatorname{trl} A m S O$, but without statistical significance. Hepatoprotective effects and renal metabolism can be exploited in other in vivo studies on the pharmacological potential of $A m S O$.

Furthermore, the identification of acetogenins in the oil suggests that this product may have pharmacological potential since these compounds mainly have anticancer activity. Annona muricata possess a wide spectrum of biological activities, and the use of their by-products or derived products, such as oil, as pharmaceutical or food ingredients is promising.

\section{CONCLUSIONS}

A. muricata seed oil (liquid fraction) ( $A m S O)$ has potential for use in food, especially due to its contents in oleic and linoleic fatty acids. $A m S O$ showed no relevant antioxidant activity and moderate phenolic compounds.

The oil precipitate (AmPtO) showed a great amount of acetogenins and was considered toxic according to the parameters evaluated in the experimental protocol in vivo. The acetogenin identified in the oil was anonacin. The toxic property of the precipitate can be associated with the presence of the acetogenin. The liquid fraction of oil (AmSO) showed no toxic properties.

Further studies on toxic action mechanisms, as well as studies concerning biological activities and pharmacological properties can be conducted to better characterize the seed oil of soursop and encourage its use in medicine.

\section{ACKNOWLEDGMENTS}

The authors thank the Coordination of Improvement of Higher Level Personnel (CAPES), National Research Council (CNPq) and Foundation of Science and Technology Support of the State of Pernambuco (FACEPE).

\section{REFERENCES}

Anuragi H, Dhaduk HL, Kumar S et al. 2016. Molecular diversity of Annona species and proximate fruit composition of selected genotypes. Biotech. 6, 1-10. https://doi. org/10.1007/s13205-016-0520-9

ANVISA- Agência Nacional de Vigilância Sanitária. 2010. Guia para a condução de estudos não clínicos de segurança necessários ao desenvolvimento de medicamentos. Gerência de Avaliação de Segurança e Eficácia - GESEF. Brasília, 01 de março de 2010. 37p.

ADAB- Agência Estadual de Defesa Agropecurária da Bahia. 2011. Produção da graviola. IOP Publishing PhysicsWeb. http://www.adab.ba.gov.br. Accessed 1 sep 2015.

Bligh EG, Dyer WJ. 1959. A rapid method of total lipid extraction and purification. Can. J. Biochem. Physiol. 37, 911917. https://doi.org/10.1139/o59-099

Champy P, Hoglinger G, Feeger J. 2002. Annonacin, the major acetogenin of Annona muricata (Annonaceae) induces neurodegeneration and astrogliosis in rats. Movement Disord. 17, 59-60.

Pedro N, de, Cautain B, Melguizo A et al. 2013. Analysis of cytotoxic activity at short incubation times reveals profound differences among Annonaceus acetogenins, inhibitors of mitochondrial Complex I. J. Bioenerg. Biomembr. 45, 145-52. https://doi.org/10.1007/s10863-012-9490-8

Dimitrios B. 2006. Sources of natural phenolic antioxidants. Trends Food Sci. Technol. 17, 505-512. https://doi. org/10.1016/j.tifs.2006.04.004

Elagbar, Z, Naik RR, Shakya AK, Bardaweel SK, 2016. Fatty Acids Analysis, Antioxidant and Biological Activity of Fixed Oil of Annona muricata L. Seeds. J. Chem. 2016, 1-6. https://doi.org/10.1155/2016/6948098

Fasakin AO, Fehintola EO, Obijole OA, Oseni OA. 2008. Compositional analyses of seed of soursop, Annona muricata L. as a potential animal feed supplement. Scientific Research and Essay 3, 521-3. https://www.academicjournals.org/SRE

Florence NT, Benoit MZ, Jonas K et al. 2014. Antidiabetic and antioxidant effects of Annona muricata (Annonaceae), aqueous extract on streptozotocin-induced diabetic rats. $J$. Ethnopharmacol. 151, 784-790. https://doi.org/10.1016/j. jep.2013.09.021 
Franzão AA, Melo B. 2007. Cultura das anonáceas: gravioleira. IOP Publishing PhysicsWeb. http://www.fruticultura.iciag. ufu.br/anonaceas.htm. Accessed 20 ago 2015.

Grzybowski A, Tiboni M, Silva MAN et al. 2012. The combined action of phytolarvicides for the control of dengue fever vector Aedes aegypti. Brazilian J. Pharmacog. 22, 549-57. https://doi.org/10.1590/S0102-695X2012005000026

Guinazi M, Milagres RCRM, Pinheiro-Sant'Ana HM, Chaves JBP. 2009. Tocoferois e tocotrienois em óleos vegetais e ovos. Quim. Nova 32, 2098-103.

Instituto Adolfo Lutz. 2008. Métodos físico-químicos para analise de alimentos 4rd edn. IAL, São Paulo.

Ishola IO, Awodele O, Olusayero AM, Ochieng CO. 2014. Mechanisms of analgesic and anti-inflammatory properties of Annona muricata L. (Annonaceae) fruit extract in rodents. J. Med. Food 17, 1375-82. https://doi.org/10.1089/ jmf.2013.0088

Lee YH, Choo C, Watawana MI et al. 2014. An appraisal of eighteen commonly consumed edible plants as functional food based on their antioxidant and starch hydrolase inhibitory activities. J. Sci. Food Agric. 95, 2956-2964.

Lerco MM et al. 2003. Caracterização de um modelo experimental de Diabetes mellitus, induzido pela aloxana em ratos. Estudo clínico e laboratorial. Acta Cir. Bras. 18, 132-142. https://doi.org/10.1590/S0102-86502003000200010

Le Ven J1, Schmitz-Afonso I, Lewin G et al. 2012. Comprehensive characterization of Annonaceous acetogenins within a complex extract by HPLC-ESI-LTQOrbitrap ${ }^{\circledR}$ using post-column lithium infusion. J. Mass Spectrom. 47, 1500-1509.

Marineli RS, Moraes EA, Lenquiste SA et al. 2014. Chemical characterization and antioxidant potential of Chilean chia seeds and oil (Salvia hispanica L.). Food Sci. Technol. 59, 1304-10. https://doi.org/10.1016/j.lwt.2014.04.014

Mayneris-Perxachs J, Sala-Vila A, Chisaguano M, Castellote AI et al. 2014. Effects of 1-year intervention with a Mediterranean diet on plasma fatty acid composition and metabolic syndrome in a population at high cardiovascular risk. PLoS One. https://doi.org/10.1371/journal. pone. 0085202

Moghadamtousi SZ, Fadaeinasab M, Nikzad S. 2015. Annona muricata (Annonaceae): A Review of Its Traditional Uses, Isolated Acetogenins and Biological Activities. Int.
J. Molecular Sci. 16, 15625-58. https://doi.org/10.3390/ ijms 160715625

Nascimento IA, Marques SSI, Cabanelas ITD et al. 2013. Screening Microalgae Strains for Biodiesel Production: Lipid Productivity and Estimation of Fuel Quality Based on Fatty Acids Profiles as Selective Criteria. Bioenergy Res. 6, 1-13. https://doi.org/10.1007/s12155$012-9222-2$

Nogueira E, Mello N, Maia M. 2005. Produção e comercialização de anonáceas em São Paulo e Brasil. Inform. Econômicas 35, 51-54.

Ritter LLN et al. 2012. Treinamento físico por natação melhora perfil hepático em ratos wistar tratados com dieta hiperlipídica. Coleção Pesquisa em Educação Física, Várzea Paulista 11, 183-190.

Roesler R, Malta L, Carrasco L et al. 2007. Atividade antioxidante de frutas do cerrado. Ciênc. Tecnol. Aliment. 27, 53-60.

Rufino M, Alves R, Brito E et al. 2006. Metodologia científica: determinação da atividade antioxidante total em frutas pelo método de redução do ferro (FRAP). Comunicado Técnico 125. Embrapa, Fortaleza, Brasil.

Rufino M, Alves R, Brito E et al. 2007. Metodologia Científica: Determinação da Atividade Antioxidante Total em Frutas pela captura do radical ABTS. Comunicado Técnico 128. Embrapa, Fortaleza, Brasil

Santos F, Albuquerque TG, Silva AS et al. 2014. Avaliação da atividade antioxidante, compostos fenólicos e flavonóides totais de quatro cultivares de anona da Madeira (Annona cherimola, Mill.) Instituto Nacional de Saúde Dr. Ricardo Jorge, Observaçôes boletim epidemiológco 2, 7-9.

Schapira AH. 2010. Complex I: inhibitors, inhibition and neurodegeneration. Exp. Neurol. 224, 331-335. https://doi. org/10.1016/j.expneurol.2010.03.028

Yu JG, Ho DK, Cassady JM et al. 1992. Cytotoxic polyketides from Annona densicoma (Annonaceae): 10,13-trans13,14-erythro-densicomacin, 10,13-trans-13,14-threodensicomacin, and 8-hydroxyannonacin. J. Org. Chem. 57, 6198-6202. https://doi.org/10.1021/jo00049a028

Zakaria ZA et al. 2011. Hepatoprotective activity of driedand fermented-processed virgin coconut oil. Evid. Based Complement Alternat. Med. 2011, 1-8. https://doi. org/10.1155/2011/142739 